\title{
Insecticidal activity of the antibiotic produced by Streptosporangium albidum against mosquito larvae
}

\author{
Takaya Iкемото* \\ Department of Parasitology', Teikyo University School of Medicine, \\ Itabashi-ku, Tokyo 17.3, Japan
}

(Received: June 29,1982)

\begin{abstract}
In the screening for insecticidal antibiotics with mosquito larvae (Culex pipiens pallens) as a test insect, the author isolated Streptosporangium albidum strain (TI-1) that produced a substance with highly insecticidal activity. From the results of the examination on cultural conditions for producing the larvicidal antibiotic in vitro, the dilutions of the culture filtrate of $1 / 8,000-1 / 10,000$ to kill $50 \%$ of 1 st instar larvae were considered as an extremely accive titre. It might be supposed that the antibiotic has not contact insecticidal ability but stomach toxicity, because it was inactive against the mosquito pupae.
\end{abstract}

\section{INTRODUCTION}

The active substances agairıst mosquito larvae produced by Streptomyces and their related microorganisms seems to be interesting in view of their potential usefulness. During the course of screening out insecticidal substances using mosquito larvae (Culex pipiens pallens) as a target organisms, the author found that a strain of Streptosporangium albidum produced in vitro a low-molecular toxic antibiotic substance. This preliminary report deals with some of the characteristics of the isolated strain; e.g., the cultural conditions suitable for producing insecticidal antibiotics and its physico-chemical nature and the biological activities.

\section{Characters of the Strain TI-1}

1. History: Isolated from soil collected at Hachijo-island, Tokyo Prefecture on August 5, 1978 on agar plate of medium (glucose $5 \mathrm{~g}$, starch $5 \mathrm{~g}$, yeast extract $0.5 \mathrm{~g}$, aspara-

* 池本孝哉：帝京大学医学部寄生虫学教室 (テ173 東京都板橋区加賀 2 丁目) gine $0.5 \mathrm{~g}, \quad \mathrm{~K}_{2} \mathrm{HPO}_{4} \cdot 7 \mathrm{H}_{2} \mathrm{O} \quad 0.5 \mathrm{~g}, \quad \mathrm{MgSO}_{4}$ $0.5 \mathrm{~g}, \mathrm{NaCl} 0.5 \mathrm{~g}, \mathrm{FeSO}_{4} \cdot 7 \mathrm{H}_{2} \mathrm{O} 0.01 \mathrm{~g}$, agar $15 \mathrm{~g}$, dist. water $1,000 \mathrm{ml}$ ). Maintained by transfer every month on the slani of medium (glucose $30 \mathrm{~g}$, beef extract $2 \mathrm{~g}$, asparagine $0.5 \mathrm{~g}, \mathrm{~K}_{2} \mathrm{HPO}_{4} 0.5 \mathrm{~g}$, agar $20 \mathrm{~g}$, dist. water $1,000 \mathrm{ml})$. Selection of potent colonies was performed occasionally by single colony isolation technique.

2. Colonies: On glucose asparagine agar plate a colony which turns into thin and white developed a cottony or floccose colony later. Reverse side of colony is pale yellow to yellowish brown. Color change of the surrounded medium was not observed.

3. Microscopic observation: Distinction between aerial and substratal mycelia is not obvious. Thread-like mycelia branched irregularly varies in width. Single sporangia, spherical to oval, is often located at an end of mycelium. Sporangiospores are arranged in a single coil within the sporangia. They are oval to elliptical, nonmotile. Sporangiospores were not observed in aqueous environments. No dehiscence of the sporangia was also observed soon after the sporangia-bearing hyphae were placed into water or liquid medium (Fig. 1). 


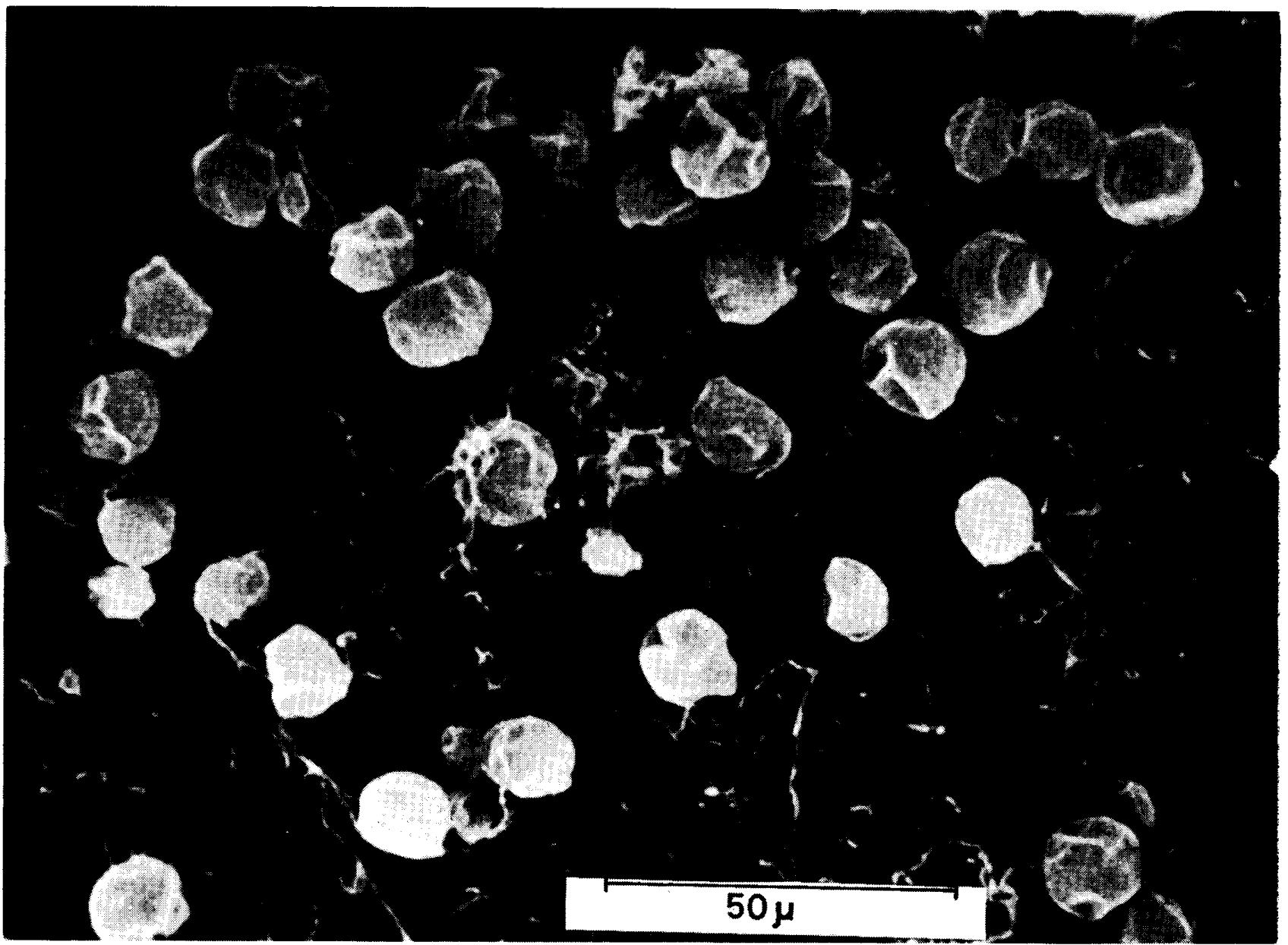

Fig. 1 Electron micrograph of the sporangium of Streptosporangium albidum on glucose asparagine agar

4. Chemical analysis of whole cells: Diaminopimelic acid is of meso-DAP type. Major sugar components are galactose, mannose, rhamnose, and minor sugar component is madurose. Therefore, the whole cell sugar pattern is of type B. The above facts suggest that cell wall type of the strain may be type III according to Becker et al. (1965).

5. Identification of the strain concerned: Many other characteristics were examined further to arrive at the difinite conclusion. As the result, this strain is a member belong to species Streptosporangium albidum Furumai et Okuda. More details will be described in a separate paper.

\section{Cultural Conditions for Pronucing the LaRvicidal Antibiotic In Vitro}

1. Methods of culture and bioassay: Cultural conditions suitable for producing larvicidal antibiotic were examined using glucose asparagine broth (glucose $30 \mathrm{~g}$, beef extract $2 \mathrm{~g}$, asparagine $0.5 \mathrm{~g}, \mathrm{~K}_{2} \mathrm{HPO}_{4} 0.5 \mathrm{~g}$, dist. water $1,000 \mathrm{ml}$ ) and its modifications. The $\mathrm{K}-1$ type flasks containing $50 \mathrm{ml}$ of the broth were inoculated with seed culture and were shaken at $200 \mathrm{rpm}$ with the use of rotary type shaker. The filtrates were assayed for antilarval activities as tollows. 30$50 \quad 1$ st instar larvae (aged one day after hatching) of Culex pipiens pallens were dipped in $8 \mathrm{ml}$ of two fold serial dilutions of culture filtrate with dechlorinated tap water at $25^{\circ} \mathrm{C}$ for $24 \mathrm{hr}$ in vessels for bioassay. A small quantity of yeast powder was added to each vessel as food.

As the antibiotic of Streptosporangium albidum has not been isolated and definitively characterized, its larvicidal activity is expressed in terms of how far the culture filtrate can be diluted and still kill $50 \%$ of the larval population. 


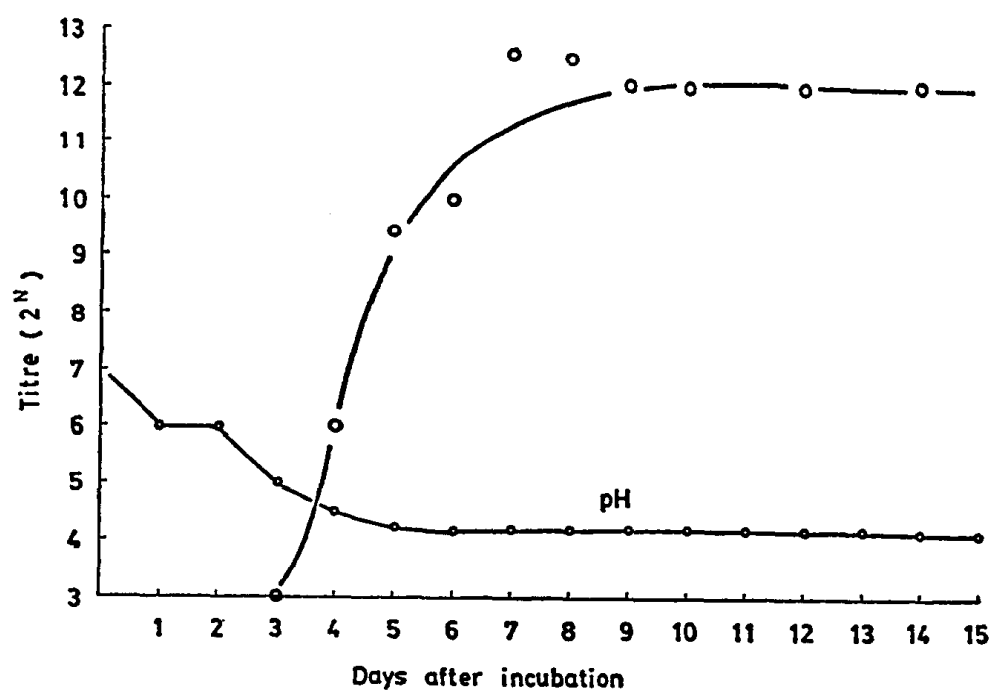

Fig. 2 Titre of insecticidal antibiotic produced in vitro by the strain in aging cultures expressed as LC.50 for 1st instar larvae of $C x$. pipiens pallens

The activities resisted $100^{\circ} \mathrm{C}$ at $\mathrm{pH} 2-7$. Samples for assay could be stored at $-25^{\circ} \mathrm{C}$.

2. Physical conditions: (Cultural temperature) Good growth was observed when the strain was cultured at temperatures ranged from $25^{\circ} \mathrm{C}$ to $30^{\circ} \mathrm{C}$. $27^{\circ} \mathrm{C}$ was seemed to be optimum.

(Initial $\mathrm{pH}$ of test broth) High levels of LC50 were obtained after 10 days incubation $\left(2^{11-12}\right)$ and 15 days incubation $\left(2^{12-14}\right)$ with the range of initial $\mathrm{pH}$ from 4.0 to 7.0. Much less LC50 was obtained with the initial $\mathrm{pH}$ of 3.0 and 8.0 or more. The levels of $\mathrm{pH}$ of the cultures yield good activities were almost 4.0 after 15 days incubation.

3. Increasing of the titre after incubation: The titre of larvicidal antibiotic produced by the strain in aging culture was shown in Fig. 2 expressed as LC50 for the mosquito larvae. Insecticidal activity appeared on 3 days after inoculation achieved a 4-fold increase in titre, and was stably maintained at high level. The medium was found to retain a given titre of the antibiotic for at least 20 days when stored aseptically.

\section{Tentative Isolation of the Antibiotic}

$n$-Buthanol extract of the fermented broth showed several spots when subjected preparative thin-layer chromatography. One of them possessed mainly the insecticidal activity. This spot could be distinguished from that of
Sporaviridin produced by a species belong to the same genus, Streptosporangium viridogriseum (Okuda et al., 1966), by comparison with their R.f. value on the thin-layer chromatography plate $\left(n-\mathrm{BuOH}: \mathrm{EtOH}: \mathrm{CH}_{3} \mathrm{Cl}_{2}\right.$ : $\left.17 \% \mathrm{NH}_{1} \mathrm{OH}=5: 4: 2: 2\right)$.

\section{INSECTICIDAL AGTIVITY}

Several reports dealing with insecticidal activity of antibiotics have appeared. It was found that Antimycin A (Kido and Spihalski, 1950), Piericidine (Tamura ot al., 1963), Cycloheximide (Harries, 1968), Aureothin (Oishi et al., 1969), Tetranactin (Ando et al., 1971) and non-isolated antibiotic produced by new species (Liu et al., 1979) produced by Streptomyces strains exert pesticidal activity. Moreover, it is known that some bacteria and other fungi can also produce exotoxins active against pests (Singer, 1973; Bulla, 1975; Rodriguez et al., 1980). For example, several soluble toxins have been reported during vegetative growth of Bacillus thuringiensis (Heimpel, 1960).

In the screening for insecticidal substances, the order of magnitude of the activity should be one of the important factors. As shown in Table 1, Fig. 2 and Fig. 3, the dilutions of the broth culture of $1 / 500$ to $1 / 10,000$ to kill $50 \%$ ( $1 / 125$ to $1 / 4,000$ to kill $100 \%$ ) of larvae of various species of mosquitoes were considered as an extremely active titre. Same titre have been expected when Bacillus 
Table 1 Insecticidal activity of the antibiotic for the larvae and pupae of Culicidae

\begin{tabular}{|c|c|c|c|c|c|}
\hline \multirow{2}{*}{ Species } & \multirow{2}{*}{ Stage } & \multicolumn{4}{|c|}{ Dilution of } \\
\hline & & \multicolumn{2}{|c|}{$50 \%$ kill } & \multicolumn{2}{|c|}{$100 \%$ kill } \\
\hline \multirow[t]{3}{*}{ Cx. pipiens pallens } & 1st instar larvae & $2^{13}(\doteqdot 8$ & $, 000)$ & $2^{12} \fallingdotseq 4$ & $, 000)$ \\
\hline & 4th instar larvae & $2^{10}(\fallingdotseq 1$ & $, 000)$ & $2^{9} \quad(\fallingdotseq$ & $500)$ \\
\hline & pupae & \multicolumn{4}{|c|}{ inactive } \\
\hline Cx. pipiens molestus & $\begin{array}{l}\text { 4th instar larvae } \\
\text { pupae }\end{array}$ & \multicolumn{3}{|c|}{ inactive } & 250) \\
\hline Ae. albopictus & $\begin{array}{l}\text { 4th instar larvae } \\
\text { pupae }\end{array}$ & $3^{9}(\doteqdot$ & $\begin{array}{l}\text { 500) } \\
\text { in }\end{array}$ & $2^{7}(\fallingdotseq$ & 125) \\
\hline Ae. togoi & $\begin{array}{l}\text { 4th instar larvae } \\
\text { pupae }\end{array}$ & $2^{9} \quad \doteqdot$ & $\begin{array}{l}\text { 500) } \\
\text { in }\end{array}$ & $2^{7}(\fallingdotseq$ & 125) \\
\hline
\end{tabular}

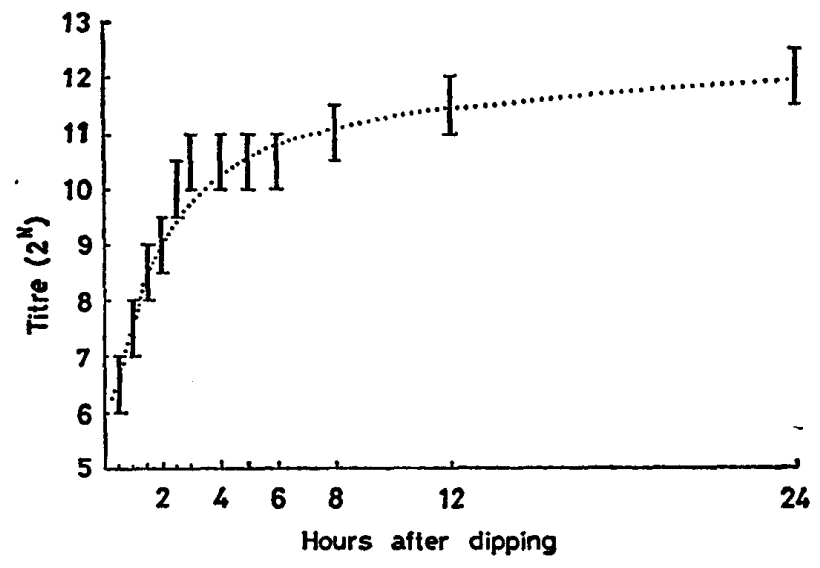

Fig. 3 Relation to the titre (dilution) which gives 50 percent mortality of 1 st instar larvae of $C x$. pipiens pallens to the hours after dipping

thuringiensis or $B$. alvei was grown in an equivalent laboratory system with the appropriate medium and tested against mosquito larvae as described by Singer (1973).

However, the antibiotic was not active against mosquito pupae as in Table 1, possibly because of the differences of morphological and/or physiological characters between mosquito larvae and pupae. Generally, mosquito pupae can freely swim but don't feed. Therefore, it is supposed that the antibiotic substance has not a contact toxicity but a stomach toxicity.

\section{AGKnowledgements}

I wish to express my gratitude to the late Prof. Y. Tsunematsu, Prof. M. Sasa and Prof. T. Kurihara, of Teikyo University for their encouragement during the course of this study. I am also grateful to Dr. A. Seino of Kaken Chemical Co., Ltd., Dr. T. Hasegawa of Takeda Chemical Ind., Ltd., Dr. T. Haneishi and Dr. A. Torikata of Sankyo Co., Ltd., for their helpful suggestions. Special thanks are extended to Mr. K. Hata, the University of Tokyo, for his providing the soil sample from which the strain TI-1 was isolated.

\section{REFERENCES}

Ando, K., H. Oishi, S. Hirano, T. Okutomi, K. Suzuki, H. Okazaki, M. Sawada and T. Sagawa (1971): Tetranactin, a new mitecidal antibiotic I. Isolation, characterization and properties of Tetranactin. J. Antibiot., 24: 347-352.

Becker, B., M. P. Lechevalier and H. A. Lechevalier (1965): Chemical composition of cell wall preparations from strains of various form genera of aerobic actinomycetes. Appl. Microbiol., 13: 236-242.

Bulla, L. A. Jr. (1975) : Bacteria as insect pathogens. Annu. Rev. Microbiol., 29: 163-190.

Harries, F. H. (1968): Further studies of effects of antibiotics and other compounds on fecundity and mortality of the two-spotted spider mite. J. Econ. Entomol., 61: 12-14.

Heimpel, A. M. (1960): Bacterial insecticides. Bacteriol. Rev., 24: 266-288.

Kido, G. S. and E. Spihalski (1950): Antimycin $A$, an antibiotic with insecticidal and miticidal properties. Science, 112: 172-173.

Liu, N., W. Huang, Y. Xie, D. Zhu, G. He, X. Yan, G. Zhang and G. Xing (1979): Culicide effect of a new species of Streptomyces. Acta Microbiol. Sin., 19: 27-33.

Oishi, H., T. Hosokawa, T. Okutomi, K. Suzuki and K. Ando (1969): Pesticidal activity of aureothin. Agric. Biol. Chem., 33: 1790-1791. 
Okuda, T., Y. Ito, T. Yamaguchi, T. Furumai, M. Suzuki and M. Tsuruoka (1966): Sporaviridin, a new antibiotic produced by Streptosporangium viridogriseum nov. sp. J. Antibiot., Ser. A, 19: 85-87.

Rodriguez, J. G., M. F. Potts and L. D. Rodriguez (1980): Mycotoxin toxicity to Tyrophagus putrescentiae. J. Econ. Entomol., 73: 282-284.

Singer, S. (1973): Insecticidal activity of recent bacterial isolates and their toxins against mosquito larvae. Nature, 244: 110-111.

Tamura, S., N. Takahashi, S. Miyamoto, R. Mori, S. Suzuki and J. Nagatsu (1963): Isolation and physiological activity of piericidine A, a natural insecticide produced by Streptomyces. Agric. Biol. Chem., 27 : 576-582.

\section{摘 要}

放線菌の一種 Streptosporangium albidum

によって産生された抗生物質の蚊 幼虫に対する殺虫効果

蚊幼虫に対し殺虫力を示す抗生物質を産生する放線 菌株が土壌中より分離された.この菌株は特徴的な胞 子のうを形成することや，細胞壁の化学組成その他の 性質から Streptosporangium albidum と同定された。 分離菌株に対する培養条件の検討が行われた結果, ア カイエカ 1 龄幼虫に対し，培養ろ液の 8,000 10,000 倍の濃度で殺虫力を示す物質が産生された.この物質 は蚊の蛹に対しては殺虫力を示さないことから，ある 種の経口毒であると推測される。 